\title{
Clostridium difficile toxins or infection induce upregulation of adenosine receptors and IL-6 with early pro-inflammatory and late anti-inflammatory pattern
}

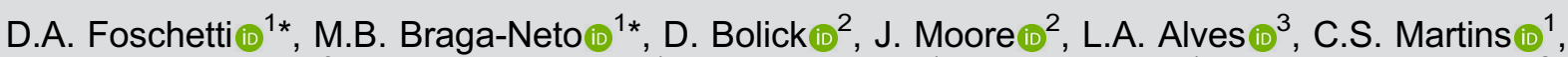 \\ L.E. Bomfin (ii) ${ }^{3}$, A.A.Q.A. Santos (i) ${ }^{1}$, R.F.C. Leitão (i) ${ }^{1}$, G.A.C. Brito ${ }^{1 *}{ }^{1 *}$, and C.A. Warren (ii) ${ }^{2 *}$ \\ ${ }^{1}$ Departamento de Morfologia, Faculdade de Medicina, Universidade Federal do Ceará, Fortaleza, CE, Brasil \\ ${ }^{2}$ Division of Infectious Diseases and International Health, University of Virginia, Charlottesville, VA, USA \\ ${ }^{3}$ Departamento de Ciências Médicas, Faculdade de Medicina, Universidade Federal do Ceará, Fortaleza, CE, Brasil
}

\begin{abstract}
Clostridium difficile causes intestinal inflammation, which increases adenosine. We compared the expression of adenosine receptors (AR) subtypes $A_{1}, A_{2 A}, A_{2 B}$, and $A_{3}$ in HCT-8, IEC-6 cells, and isolated intestinal epithelial cells, challenged or not with Clostridium difficile toxin $A$ and $B$ (Tcd $A$ and TcdB) or infection (CDI). In HCT-8, TcdB induced an early $A_{2 B} R$ expression at $6 \mathrm{~h}$ and a late $A_{2 A} R$ expression at 6 and $24 \mathrm{~h}$. In addition, both TcdA and TcdB increased IL- 6 expression at all time-points (peak at $6 \mathrm{~h}$ ) and PSB603, an $A_{2 B} R$ antagonist, decreased IL-6 expression and production. In isolated cecum epithelial cells, TcdA induced an early expression of $A_{2 B} R$ at 2 and $6 \mathrm{~h}$, followed by a late expression of $A_{2 A} R$ at 6 and $24 \mathrm{~h}$ and of $A_{1} R$ at $24 \mathrm{~h}$. In CDI, $A_{2 A} R$ and $A_{2 B} R$ expressions were increased at day 3 , but not at day 7 . ARs play a role in regulating inflammation during CDI by inducing an early pro-inflammatory and a late anti-inflammatory response. The timing of interventions with AR antagonist or agonists may be of relevance in treatment of CDI.
\end{abstract}

Key words: Clostridium difficile; Clostridium difficile toxins; Adenosine; $\mathrm{A}_{2 \mathrm{~A}}$ adenosine receptor; $\mathrm{A}_{2 \mathrm{~B}}$ adenosine receptor

\section{Introduction}

Clostridium difficile (C. difficile) is a major cause of antibiotic-associated diarrhea in hospitalized patients (1). Since the early 2000's, considerable changes in the epidemiology and severity of $C$. difficile infection (CDI) have been observed worldwide, which has been related to the rise of more virulent strains such as NAP1/B1/027 (2-4).

This anaerobic bacterium produces two major exotoxins, toxin $A(\operatorname{Tcd} A)$ and toxin B (TcdB), both with glucosyltransferase activity, which permanently inactivates Rho GTPases causing disaggregation of actin cytoskeleton, activation of caspases, and intestinal cell damage $(5,6)$. In vitro, both $\mathrm{TcdA}$ and $\mathrm{TcdB}$ decrease intestinal cell migration and proliferation and induce apoptosis by activation of extrinsic and intrinsic apoptosis pathways (7-9). We have previously demonstrated that TcdA attenuates $\mathrm{Wnt} / \mathcal{B}$-catenin signaling in intestinal epithelial cells, which is associated with anti-proliferative effects (10). In animal models, these toxins also cause intestinal secretion, intense destruction of the mucosa, hemorrhage, and accentuated tissue inflammation with neutrophil infiltration and production of cyclooxygenase-2, prostaglandin E2, and inflammatory cytokines such as tumor necrosis factor (TNF)- $\alpha$ and interleukin (IL)-1 $\beta$, IL-6, and IL-8 $(11,12)$. Treatment of CDI still relies on antimicrobial agents such as vancomycin or fidaxomycin (13). Unfortunately, antimicrobial therapy may create a susceptible environment for reinfection or relapse by disrupting the gut microbial flora (14). Furthermore, a subset of patients can be refractory to available medical therapy, including fecal transplant, highlighting the need for novel treatment options.

Adenosine, an endogenous purine nucleoside, accumulates in the extracellular space during stressful conditions, such as ischemia, hypoxia, and inflammation, and

Correspondence: G.A.C. Brito: <gerlybrito@hotmail.com>

${ }^{*}$ These authors contributed equally to this work.

Received February 22, 2020 | Accepted May 29, 2020 
modulates the immune and inflammatory responses (15). Adenosine elicits its effects through four transmembrane adenosine receptors: $A_{1}, A_{2 A}, A_{2 B}$, and $A_{3}$, which all act on mitogen-activated protein kinase pathways (MAPK) (16). Receptors $A_{1}$ and $A_{3}$ increase concentration of calcium, while receptors $A_{2 A}$ and $A_{2 B}$ increase cyclic AMP. While activation of receptor $A_{2 A}$ induces an anti-inflammatory response, activation of receptor $A_{2 B}$ is associated with a pro-inflammatory response $(17,18)$. Indeed, we have demonstrated in vitro and in vivo that $A_{2 A}$ agonists or $A_{2 B}$ antagonist can ameliorate $C$. difficile colitis $(19,20)$. Interestingly, the expression, distribution, and co-localization of these receptors in the gastrointestinal tract intestine varies between cell types (21), highlighting the importance of investigation of the cell-specific roles of $A_{2 A} R$ and $A_{2 B} R$.

In this study, we evaluated the expression of $A R$ specifically in isolated cecum epithelial cells following CDI or exposure to TcdA and found a time-dependent expression pattern of $A_{2 B}$ and $A_{2 A}$. Similar results were observed in vitro following exposure to $\mathrm{Tcd} A$ and $\mathrm{TcdB}$ and correlated with expression of IL-6, a pro-inflammatory cytokine.

\section{Material and Methods}

\section{Cell culture}

A human ileocecal epithelial cell line, HCT-8 cells (passages 20-30), were grown in filtered RPMI medium 1640 in the presence of $10 \%$ fetal bovine serum, $1 \mathrm{mM}$ sodium pyruvate, and $0.1 \mathrm{unit} / \mathrm{mL}$ of penicillin/streptomycin (Gibco, cat \#15140, USA). Rat intestinal jejunal crypt cells, IEC-6 cells (passages 17-30), were grown in Dulbecco's modified Eagle's medium (DMEM) supplemented with 10\% fetal bovine serum (Gibco), $1 \mathrm{mM}$ sodium pyruvate, 95\% bovine insulin, and 0.1 unit of pen/strep. All cells were maintained in a humidified incubator at $37^{\circ} \mathrm{C}$ and $5 \% \mathrm{CO}_{2}$. Trypsin-EDTA-dissociated HCT-8 cells, in $200 \mu \mathrm{L}$ of the medium, were seeded in a 6 -well plate. Upon $80 \%$ confluence, the cells were treated with TcdA or TcdB $(0.01,0.1,1,10$, and $100 \mathrm{ng} / \mathrm{mL})$ and were incubated for 2,6 , and $24 \mathrm{~h}$.

\section{Murine cecal injection model}

We performed the murine cecal injection as previously described (22). This protocol was approved by the Center for Comparative Medicine at the University of Virginia (USA). C57BL/6 male mice, weighing 23-25 g each, were fasted overnight. The mice were anesthetized with ketamine $(60-80 \mathrm{mg} / \mathrm{kg})$ and xylazine $(5-10 \mathrm{mg} / \mathrm{kg})$, administered intramuscularly. A midline abdominal incision was made to expose the cecum. After flushing with PBS, $20 \mu \mathrm{g}$ of toxin A in $100 \mu \mathrm{L}$ of $0.9 \%$ normal saline was injected into the distal tip. Incisions were sutured (nylon 3-0, Procare, Brazil) (time 0) for 2, 6, or $24 \mathrm{~h}$ and animals were monitored during recovery. Sham-injected animals received only $100 \mu \mathrm{L}$ of saline and animals were monitored during recovery. Any moribund (i.e., hunched posture, ruffled coat, or little to no movement) mouse was immediately euthanized. In animal studies, TcdA appears to be the dominant virulence factor compared to TcdB $(23,24)$. Therefore, we chose to use TcdA, not TcdB, in the murine model.

\section{Isolation of cells from cecal tissue}

The cecum epithelial cells isolation protocol was followed according D'Auria et al. (22). A cross-section from the middle of each cecum was dissected and opened longitudinally, rinsed with Hank's balanced salt solution (HBSS; Gibco), and shaken at $250 \mathrm{rpm}$ for $30 \mathrm{~min}$ at $37^{\circ} \mathrm{C}$ in HBSS containing $50 \mathrm{mM}$ EDTA and $1 \mathrm{mM}$ dithiothreitol (DTT) in order to remove epithelial-layer cells. The digested tissue was strained with a $100-\mu \mathrm{m}$ cell strainer and the filtrate was centrifuged $\left(1,000 \mathrm{~g}, 4^{\circ} \mathrm{C}, 10 \mathrm{~min}\right)$. Cells were resuspended in red-cell lysis buffer $\left(150 \mathrm{mM} \mathrm{NH}_{4} \mathrm{Cl}\right.$, $10 \mathrm{mM} \mathrm{NaHCO}, 0.1 \mathrm{mM}$ EDTA) and centrifuged again. The pelleted cells were stored at $-80^{\circ} \mathrm{C}$ for further RNA isolation and cytokine quantification.

\section{Murine model of $\boldsymbol{C}$. difficile infection}

The infection model was a modification of a previously described protocol (25). This protocol has been approved by the Center for Comparative Medicine at the University of Virginia. From 6 to 4 days prior to infection, C57BL/ 6 mice were given an antibiotic cocktail containing vancomycin $(0.0045 \mathrm{mg} / \mathrm{g})$, colistin $(0.0042 \mathrm{mg} / \mathrm{g})$, gentamicin $(0.0035 \mathrm{mg} / \mathrm{g})$, and metronidazole $(0.0215 \mathrm{mg} / \mathrm{g})$ in drinking water. One day prior to infection, clindamycin (32 $\mathrm{mg} / \mathrm{kg}$ ) was injected subcutaneously. Infection was performed with strain VPI 10463 at an inoculum of $10^{5}$ cells administered by oral gavage. The uninfected control group received only the vehicle. A group of infected and uninfected mice were sacrificed by cervical dislocation under sedation (ketamine-xylazine) on day 3 and at the end of the experiment (day 7). Cecal tissues were harvested and frozen until mRNA extraction and AR gene expression assay were performed.

\section{Adenosine receptor subtype assay}

Adenosine receptor subtype $\left(A_{1}, A_{2 A}, A_{2 B}\right.$, and $\left.A_{3}\right)$, was assayed by quantitative PCR (qPCR) in IEC-6, HCT8 , or in mouse cecum epithelial cells. Purified TcdA and TcdB were provided by David Lyerly from TECHLAB, Inc. (USA). Each sample was suspended in $350 \mu \mathrm{L}$ of RLT lysis buffer and the RNA was extracted using Qiagen RNeasy mini kit (USA), according to manufacturer's instructions. RNA was quantified by standard spectrophotometry (Biophotometer, Eppendorf, Germany). In order to remove the genomic DNA carried over from RNA extraction, DNase I (Ambion, USA) treatment was performed following the manufacturer's instructions. Synthesis of cDNA by reverse transcriptase PCR was performed using SuperScript III First-Strand Synthesis System 
SuperMix (Invitrogen, USA) with the use of oligo (dT) as primers. CDNA was used in quantitative PCR for measuring $A_{1}, A_{2 A}, A_{2 B}$, and $A 3$ expression compared to GAPDH expression. The Invitrogen Fast SYBR green cells-to-CT one-step kit was used according to the manufacturer's instructions, as previously described (26). The relative gene expression was determined using the $2-\Delta \Delta \mathrm{Ct}(25)$ method using GAPDH as the housekeeping gene.

\section{Cytokine gene assay}

Total cellular RNA extraction from each intestinal tissue, analysis, cDNA conversion, and qPCR protocol are described above $(26,27)$. The primers used for both adenosine subtype and cytokine gene expression are listed on Table 1.

\section{Cytokine quantification by ELISA}

IL-6 concentrations in cecum tissue were measured by enzyme-linked immunosorbent assay (ELISA) as described previously (28).

\section{Immunohistochemical reaction for IL-6}

Immunohistochemistry (IHC) for IL-6 was performed in cecum tissue using the streptavidin-biotin-peroxidase method (29) in formalin-fixed, paraffin-embedded tissue sections $(4-\mu \mathrm{m}$ thick) mounted on poly(I)-lysine-coated microscope slides. Sections were incubated overnight $\left(4^{\circ} \mathrm{C}\right.$ ) with primary rabbit anti-mouse IL-6 (Santa Cruz Biotechnology, USA) in PBS plus bovine serum albumin (PBS-BSA). The slides were then incubated with biotinylated goat anti-rabbit $\lg G$ and diluted in PBS-BSA. After being washed, the slides were incubated with avidinbiotin-horseradish peroxidase conjugate ( $A B C$ complex; Santa Cruz Biotechnology) for $30 \mathrm{~min}$ according to the manufacturer's protocol. IL-6 was visualized with chromogen 3,3'diaminobenzidine (DAB). Negative-control sections were processed simultaneously as described above but

Table 1. List of primer sequences for reverse transcription-qPCR analyses.

\begin{tabular}{lll}
\hline Gene & Primers & \multicolumn{1}{c}{ Sequence } \\
\hline A $_{1}$ AR & Forward & GCGGTGAAGGTGAC \\
& Reverse & AGGCAGGTGTGGAAG \\
A $_{2 \mathrm{~A}}$ AR & Forward & AGTTCCGCCAGACCTTCC \\
& Reverse & AGTTCCGCCAGACCTTCC \\
$\mathrm{A}_{2 \mathrm{~B}}$ AR & Forward & GGTCATTGCTGTCCTCTG \\
& Reverse & CAGGTGAGCCAGCAAGATC \\
$\mathrm{A}_{3}$ AR & Forward & AGGGTAGGATGAGCAAGTTG \\
& Reverse & CAGGTGAGCCAGCAAGATC \\
GAPDH & Forward & AGGTCGGAGTCAACGGATTTGGT \\
& Reverse & CATGTGGGCCATGAGGTCCACCAC \\
IL-6 & Forward & ACAAGTCGGAGGCTTAATTACACAT \\
\hline
\end{tabular}

with the first antibody being replaced by PBS-5\% BSA. Slides were counterstained with Harris hematoxylin (Dinâmica, Brazil).

\section{Statistical analysis}

Data are reported as means $\pm \mathrm{SE}$, as generated by GraphPad Prism version 5.0 (GraphPad Software, USA). The differences between experimental groups were evaluated using one-way analysis of variance (ANOVA) with Bonferroni's multiple comparison test. Student's $t$-test
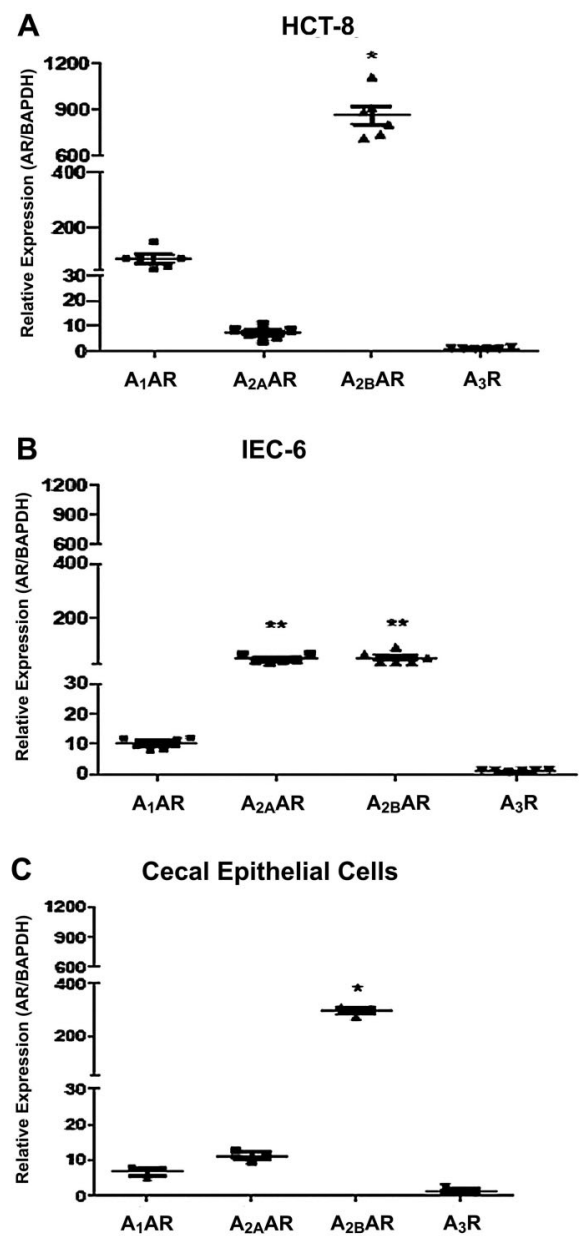

Figure 1. Adenosine receptor (AR) gene expression in intestinal human (HCT-8) and rat (IEC-6) cells and isolated cecal epithelial cells. HCT-8 (A) and IEC-6 (B) cells were incubated with specific media and, after achieving confluence, cells were harvested and mRNA were extracted and analyzed by qPCR. C, The cecum epithelial cells from mice ( $n=6$ per group) were isolated and the mRNA was extracted for $A_{1} A R, A_{2 A} A R, A_{2 B} A R$, and $A_{3} A R$ analysis by qPCR. Each assay was performed in triplicate per time-point. ${ }^{*} P<0.05$, compared with $A_{1} A R, A_{2 A} A R$, and $A_{3} A R$; ${ }^{* *} P<0.05$, compared with $A_{1} A R$ and $A_{3} A R$ (one-way ANOVA with Bonferroni post-test). Vertical lines indicate mean $\pm S E$. 
was performed to analyze differences between 2 groups. Statistical significance was set at $P \leqslant 0.05$.

\section{Results}

$A_{2 B} R$ was the predominant $A R$ expressed in intestinal epithelial cells

The mean of $A_{2 B}$ mRNA expression was 10-fold higher $(P<0.05)$ than that of $A_{1}$ and $>150$-fold higher $(P<0.05)$ than those of $A_{2 A}$ and $A_{3}$ transcripts in HCT8 cells at baseline (Figure 1A). However, in IEC-6 cells, both $A_{2 A}$ and $A_{2 B}$ mRNAs were significantly more expressed than $A_{1}$ and $A_{3}$ (Figure 1B). In cecum epithelial cells isolated from healthy mice, mRNA levels of $A_{2 B}$ were significantly higher than all other $A R s$ followed by $A_{2 A}$, as shown in Figure $1 \mathrm{C}$. Therefore, for our in vitro experiments of TcdA and TcdB intoxication, HCT-8 cells were used, as its adenosine receptor pattern more closely resembled cecal epithelial cells compared to IEC-6 cells.

\section{TcdA and TcdB upregulated AR expression in HCT-8 cells}

To test whether $C$. difficile toxins affect $A R$ expression in vitro, we incubated HCT-8 cells with TcdA or TcdB. $A_{2 B}$ mRNA significantly increased after 2 and $6 \mathrm{~h}$ of exposure to $10 \mathrm{ng} / \mathrm{mL}$ TcdB (Figure $2 \mathrm{C}$ ). $A_{2 A}$ mRNA significantly increased after 6 and $24 \mathrm{~h}$ of exposure to TcdB (Figure 2B). TcdA at $10 \mathrm{ng} / \mathrm{mL}$ significantly increased $A_{2 B}$ and $A_{2 A}$
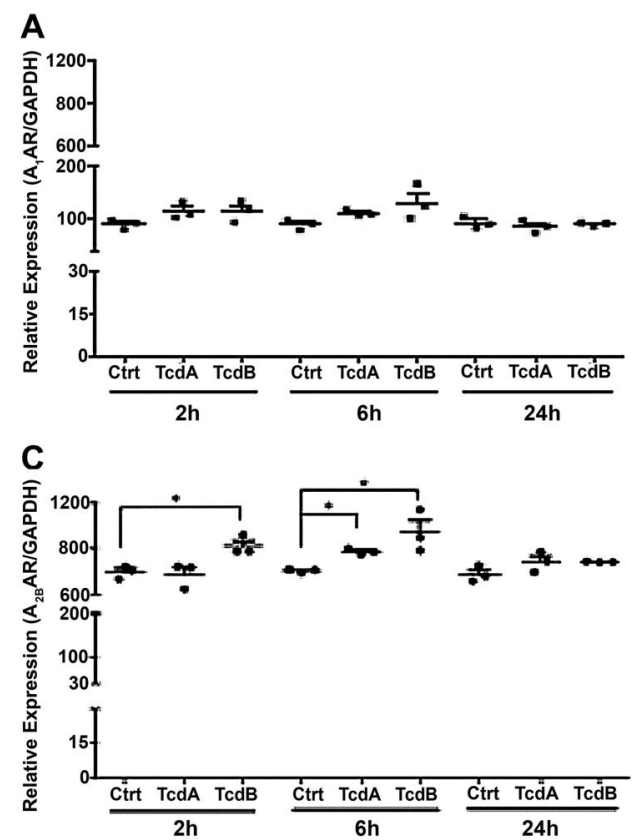

transcript expression after $6 \mathrm{~h}$ and $24 \mathrm{~h}$ of exposure, respectively. There was no significant difference in $A 1$ or A3 mRNA expression in response to TcdA and TcdB (Figure 2A and D).

\section{C. difficile toxin-induced IL-6 secretion was mediated by $A_{2 B} R$}

Because both TcdB and TcdA predominantly induced the expression of $A_{2 B}$ in HCT-8, we investigated whether this was associated with IL-6 gene expression by using PSB603, a specific $A_{2 B}$ antagonist. TcdB increased IL-6 gene expression by 1.6-, 7.4-, and 1.6-fold at 2, 6, and $24 \mathrm{~h}$, respectively (Figure 3 ).

Incubation with $\mathrm{A}_{2 \mathrm{~B}}$ antagonist, PSB603, significantly decreased IL- 6 secretion at 2, 6, and $24 \mathrm{~h}$. Consistent with the timing of peak $A_{2 B}$ expression, IL- 6 gene expression also peaked at $6 \mathrm{~h}$ with TcdB stimulation.

\section{TcdA and $C$. difficile infection induced AR expression in isolated cecum epithelial cells}

To test the effect of $C$. difficile toxins in AR expression in vivo, we injected mouse cecal loops with $\operatorname{Tcd} A$ as we had previously demonstrated that TcdA, and not TcdB, induced consistent histopathological findings in both mouse and rabbit intestinal tissues $(28,29)$. After 2, 6, and $24 \mathrm{~h}$ of exposure, epithelial cells isolated from cecal tissues challenged with TcdA had significantly higher mRNA levels of $A_{1}, A_{2 A}$, and $A_{2 B}$ subtypes compared to
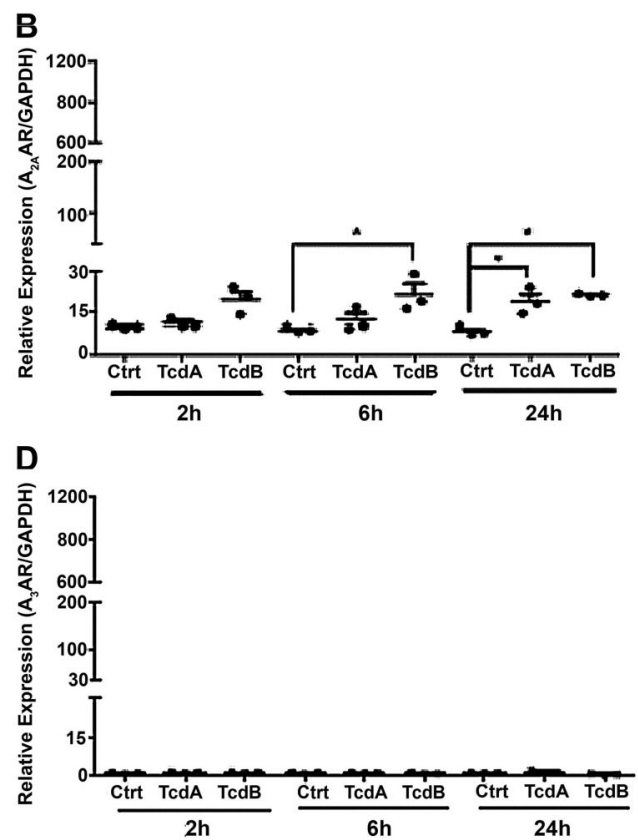

Figure 2. Effect of $C$. difficile toxins on adenosine receptor $(A R)$ expression in vitro. HCT-8 cells were intoxicated with TcdA or TcdB $(10 \mathrm{ng} / \mathrm{mL})$ for 2,6 , and $24 \mathrm{~h}$. Analyses of $A_{1} A R(A), A_{2 A} A R(B), A_{2 B} A R(C)$, and $A_{3} A R(D)$ mRNA expression were performed by qPCR. Each assay was performed in triplicate per time-point. ${ }^{*} \mathrm{P}<0.05$ compared with control (Ctrl) (one-way ANOVA with Bonferroni posttest). Vertical lines indicate mean \pm SE. 

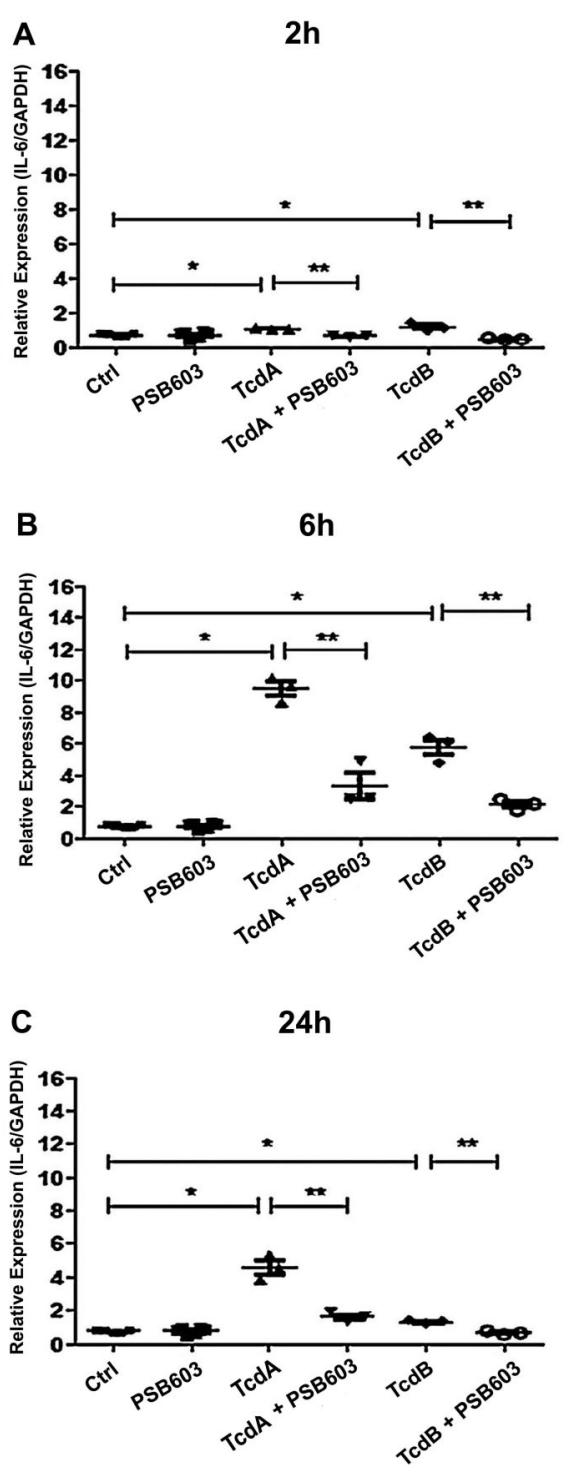

Figure 3. Effect of $A_{2 B} A R$ antagonist (PSB603) on C. difficileinduced interleukin (IL)-6 gene expression in vitro. HCT-8 cells were incubated with $T c d A$ and $T c d B$ at $10 \mathrm{ng} / \mathrm{mL}$ with or without PSB603. Analyses of IL-6 mRNA expression at 2 (A), 6 (B), and 24 (C) $\mathrm{h}$ were performed by $\mathrm{qPCR}$. Each treatment was done in triplicate per time-point. ${ }^{*} \mathrm{P}<0.05$, ${ }^{* *} \mathrm{P}<0.05$ (oneway ANOVA with Bonferroni post-test). Vertical lines indicate mean \pm SE.

their respective controls (Figure 4). $A_{2 B} R$ subtype expression significantly increased at 2 and $6 \mathrm{~h}$ (Figure $4 \mathrm{C}$ ), $\mathrm{A}_{2 \mathrm{~A}} \mathrm{R}$ at 6 and 24 (Figure 4B), and $A_{1}$ only at $24 \mathrm{~h}$ (Figure 4A). No significant difference in $A_{3} R$ mRNA expression levels was observed (Figure 4D). Again, $A_{2 B}$ levels were the most highly expressed amongst the AR subtypes, with peak expression at $6 \mathrm{~h}$ of incubation. To evaluate the effect of C. difficile infection on AR subtype expression, we harvested cecal tissues from infected mice at days 3 (infection peak) and 7 (recovery period) post-infection. Cecal tissues harvested at day 3 post-infection with C. difficile had higher $A_{2 A}$ and $A_{2 B}$ mRNA expressions compared to their respective uninfected controls (Figure $5 A-D)$. At day 7 post-infection, no significant differences in $A_{2 A}$ and $A_{2 B}$ mRNA expressions were observed compared to uninfected controls but there was a significant decrease in both $A_{2 A}$ and $A_{2 B}$ mRNA expressions at day 7 compared to infected mice at day 3 . No significant differences regarding mRNA levels of $A_{3}$ were observed among the groups (Figure 5D)

\section{C. difficile toxin-induced IL-6 secretion decreased with the $A_{2 B} R$ blockage in vivo}

IL-6 concentration in murine cecal epithelial cells intoxicated with TcdA was evaluated by ELISA and IHC. After $2 \mathrm{~h}$ of exposure, there was no difference in IL-6 production. However, 6 hours after TcdA incubation, IL-6 production and immunoreactivity increased significantly in cecal enterocytes compared to the control group (Figure $6 A$ and $B$ ). The animals intoxicated with $T c d A$ and treated with the $A_{2 B}$ antagonist PSB603 had significantly lower IL6 levels and immunoreactivity than untreated mice.

\section{Discussion}

In this study, we demonstrated for the first time the expression of AR subtypes specifically in isolated cecal epithelial cells in a murine model of CDI or TcdA intoxication and identified a distinct expression pattern during early and late infection, contributing to the understanding of the cell-specific pathogenesis of CDI. Indeed, we also confirmed in vitro using a human intestinal cell line, $\mathrm{HCT}-8$, that $\mathrm{A}_{2 \mathrm{~B}}$ expression increased at earlier timepoints of intoxication while $A_{2 A}$ increased at later timepoints.

Previously, we have demonstrated the effect of TcdA and $\mathrm{TcdB}$ on the expression of adenosine receptors after 2 and $4 \mathrm{~h}$ of intoxication in HCT-8 cells (19). The present work used short-term ( 2 and $6 \mathrm{~h}$ ) and, importantly, longterm incubation with TcdA or TcdB $(24 \mathrm{~h})$, demonstrating the effect on adenosine receptors both in vitro (HCT-8 cells) and in vivo (cecal epithelial cells), and the effect of infection with the microorganism on adenosine receptors. The short-term effects of toxins $A$ and $B$ on the expression of adenosine receptors in HCT-8 cells demonstrated in the current study corroborated previously published findings, suggesting that intestinal epithelial cells upregulate $A_{2 B} A R$ mRNA expression in response to $C$. difficile toxins (19).

We have previously shown that the $A_{2 A} R$ agonist, ATL313, significantly decreased intestinal damage and TNF- $\alpha$ production induced by $C$. difficile TcdA in mice (20). A subsequent study combining $A_{2 A} R$ agonist therapy (ATL370) with alanlyl-glutamine supplementation demonstrated improvement of intestinal damage and increased 

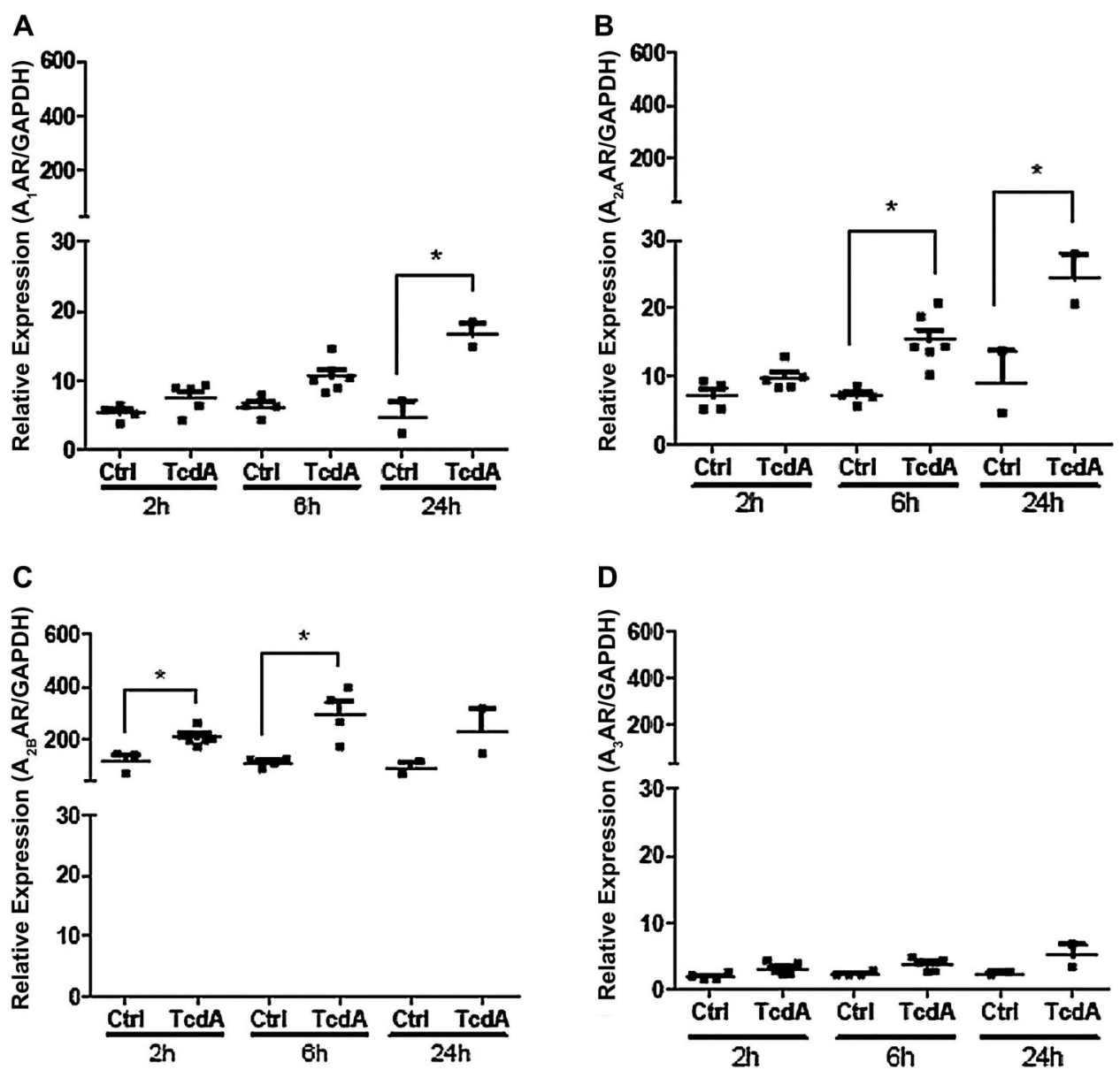

Figure 4. Effects of $C$. difficile TcdA on the adenosine receptors (AR) gene expression in cecal epithelial cells. The murine cecum ( $\mathrm{n}=6 /$ group) was injected with TcdA ( $20 \mu \mathrm{g} / \mathrm{loop})$ and incubated for 2, 6, and $24 \mathrm{~h}$. The cecal epithelial cells were isolated and mRNA was extracted for $A_{1} A R(A), A_{2 A} A R(B), A_{2 B} A R(C)$, and $A_{3} A R(D)$ analysis by qPCR. ${ }^{*} P<0.05$ compared with control (Ctrl) (one-way ANOVA with Bonferroni post-test). Vertical lines indicate mean \pm SE.

IL-10 levels during TcdA intoxication (19). In the present study, by isolating the cecal epithelial, cells in vivo, we were able to evaluate separately the effect of TcdA on adenosine receptor expression and have found that $A_{2 B}$ is the most highly expressed amongst the AR subtypes. In fact, according to the literature, $A_{2 A}$ may be more localized in immune rather than epithelial cells in the intestinal tract (30). In accordance, in macrophages, $A_{2 A}$ receptor activation decreases secretion of inflammatory cytokines, such as TNF- $\alpha$ and IL-6 and increases IL-10 $(31,32)$.

Several studies have confirmed the $A_{2 B} R$ pro-inflammatory role by demonstrating that $A_{2 B} R$ blockade with selective antagonists decreases IL-6 levels and neutrophil activation, resulting in decreased intestinal damage in mice suffering from colitis $(33,34)$ or infected with $C$. difficile (19). In HCT-8 cells and cecum epithelial cells, TcdA- or TcdBinduced IL- 6 secretion is significantly decreased by $A_{2 B} R$ blockade. Additionally, it was seen that blocking or knockdown of $A_{2 B} R$ caused a significant decrease in IL-6 secretion by the enterocytes and submucosal cells in infected animals, suggesting that the expression of proinflammatory cytokines such as IL- 6 by intestinal epithelial cells are induced via $A_{2 B} R$ stimulation and activation of its intracellular signaling pathway (19).

In this study, we evaluated the effect of TcdA on AR subtype expression specifically in isolated mouse cecal epithelial cells. Although both TcdA and TcdB are important for pathogenesis, we did not use TcdB in our murine model experiments since it has been previously shown that rabbits, hamsters, and mice are more responsive to TcdA, compared with TcdB (35-37). TcdA increased the expression of all AR subtypes. Specifically, TcdA induced an early peak ( 2 and $6 \mathrm{~h}$ ) of $\mathrm{A}_{2 \mathrm{~B}}$ and a late peak $\left(6\right.$ and $24 \mathrm{~h}$ ) of $A_{2 A}$. We also found that $A_{1 R}$ expression was increased at $24 \mathrm{~h}$. Adenosine $A_{1}$ is known to have 

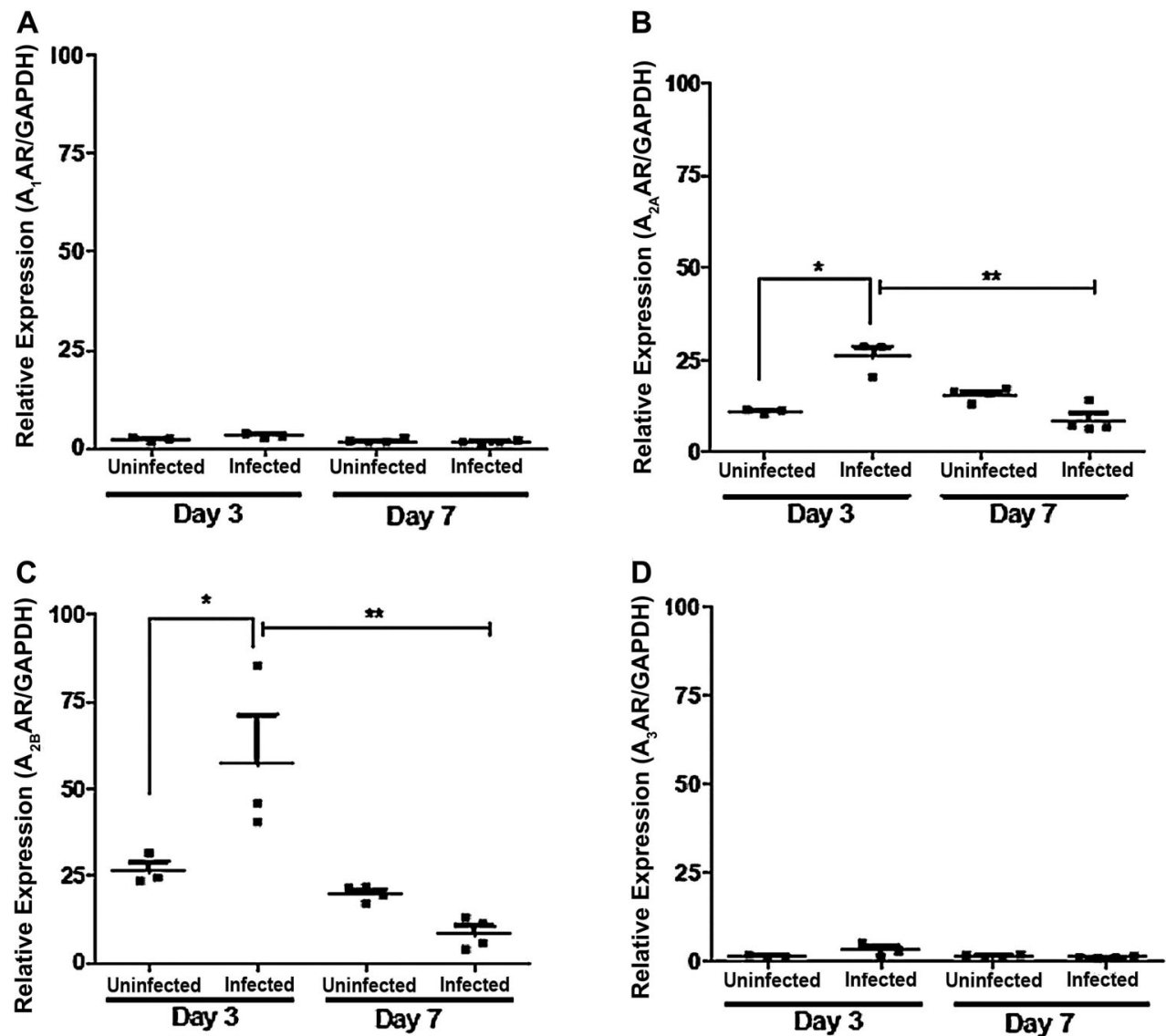

Figure 5. Effects of $C$. difficile infection on the $A R$ in cecal tissue. Mice ( $n=3$ to $4 /$ group) were infected with $C$. difficile ( $10^{5} \mathrm{CFU}$, colony forming units) and were sacrificed at either 3 or 7 days after the infection. mRNA was extracted from cecal tissues for $A_{1} A R(A), A_{2 A} A R$ (B), $A_{2 B} A R(C)$, and $A_{3} A R(D)$ analysis by qPCR. ${ }^{*} P<0.05$ compared with uninfected mice; ${ }^{* *} \mathrm{P}<0.05$ compared with infected mice at day 3 (one-way ANOVA with Bonferroni post-test). Vertical lines indicate mean \pm SE.

predominantly a pro-inflammatory effect. However, since $A_{2 B}$ was shown to be the predominant $A R$ expressed in cecal epithelial cells, we believe that the overall inflammatory state was more closely linked to $A_{2 B}$ expression.

Using a murine model of CDI, we isolated the intestinal cecum epithelial cells in mice at days 3 and 7 postinfection with $C$. difficile and assessed the AR subtype expression pattern. We found that infection increased the expression of $A_{2 A}$ and $A_{2 B}$ at day 3 , compared to uninfected controls, with a predominance of $A_{2 B}$. During the infection recovery (day 7), expression of both receptors was significantly decreased. These findings are consistent with our previous studies suggesting the potential critical role of $A_{2 B}$ activity in the pathogenesis of $C D I$ (19) and support the role of $A_{2 A}$ in controlling inflammation-induced damage.

Considering that HCT8 is a human cell line and more closely resembled the AR subtype pattern observed in isolated cecal epithelial cells in vivo compared to rat intestinal epithelial cells, we chose this cell line to evaluate the effect of TcdA and TcdB over time on the expression of AR subtypes in vitro. Pro-inflammatory cascade likely predominated at early time points of intoxication as supported by an early peak of $A_{2 B} R$ expression, followed later by the anti-inflammatory cascade as supported by a late peak of $A_{2 A} R$ expression. We hypothesized that, initially, there is a peak of pro-inflammatory cytokines, such as IL-6, in the intestinal epithelium that may result in the activation of macrophages and the recruitment of neutrophils to control infection. However, following the massive release of pro-inflammatory cytokines and production of free radicals, the intestinal epithelium possibly shifts towards an anti-inflammatory milieu to limit the tissue damage induced by exaggerated immune and proinflammatory responses. Similarly, dendritic cells when mature express higher levels of $A_{2 A}$, switching from a pro- to an anti-inflammatory response, with increased levels of IL-10 and lower levels of IL- 1 beta, TNF- $\alpha$, and IFN-gamma (38-40). 
A
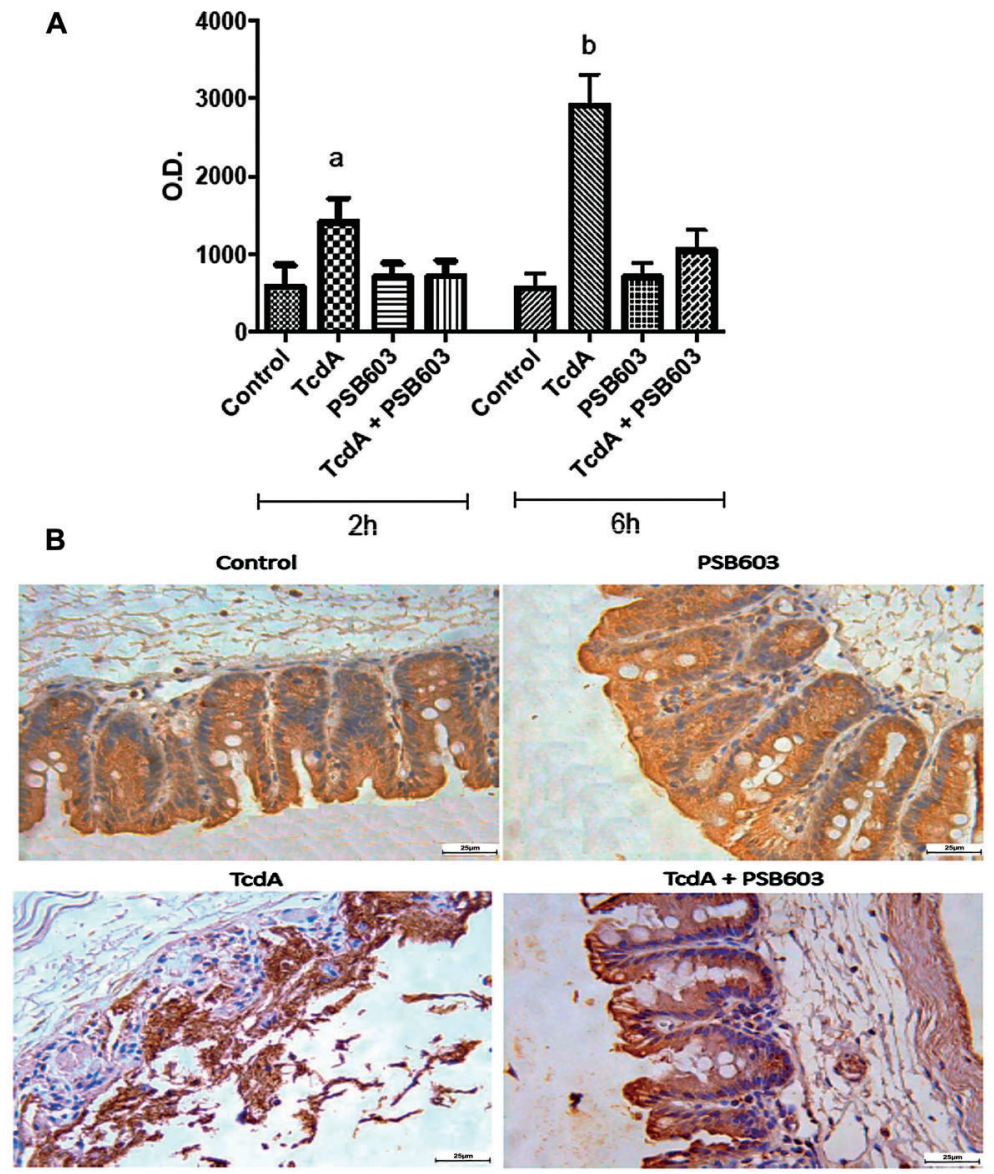

Figure 6. Effect of $A_{2 B} A R$ antagonist (PSB603) on C. difficile-induced interleukin (IL)-6 production in vivo. The murine cecum ( $n=6 /$ group) was injected with TcdA ( $20 \mu \mathrm{g} / \mathrm{loop})$ with or without PSB603 $(5 \mu \mathrm{M})$ and incubated for 2 and $6 \mathrm{~h}$. The cecum epithelial cells were isolated and IL-6 production was detected by ELISA and reported as absorbance (O.D.) units (A). ${ }^{a} \mathrm{P}<0.05$ compared with Ctrl $2 \mathrm{~h}$; ${ }^{\mathrm{b}} \mathrm{P}<0.05$ compared with Ctrl $6 \mathrm{~h}$ (one-way ANOVA with Bonferroni post-test). Data are reported as mean $\pm \mathrm{SE}$. B, The presence of IL- 6 in the enterocytes from cecal tissues was detected by immunohistochemistry. Representative tissues shown were harvested at $6 \mathrm{~h}$ (scale bar $25 \mu \mathrm{m}$ ).

In conclusion, we demonstrated that $C$. difficile toxins upregulate predominantly $A_{2 A}$ and $A_{2 B}$ subtypes in the intestinal epithelium, with an early expression of $A_{2 B}$ and IL-6, followed by a late $A_{2 A}$ gene expression. $A_{2 B}$ appears to be critical for IL-6 gene expression and production in HCT8 and cecum epithelial cells. Similarly, in our infection model, $A_{2 B}$ seemed to be the predominant AR expressed during acute infection, which may partially explain the highly inflammatory feature of the $C$. difficile-associated diarrhea. Our findings provide insight into the sequence of events in adenosine receptor subtype expression upon

\section{References}

1. Rupnik M, Wilcox MH, Gerding DN. Clostridium difficile infection: new developments in epidemiology and pathogenesis. exposure to toxins and the potential importance of timing of intervention to maximize potential beneficial outcomes of treatment following $C$. difficile infection.

\section{Acknowledgments}

This work was supported by the Brazilian National Council for Scientific and Technological Development, PRONEX/FUNCAP/CNPq through grant PR2 0101-00060. $01.00 / 15$, and partially supported by R21A119418 and U19Al109776.
Nat Rev Microbiol 2009; 7: 526-536, doi: 10.1038/ nrmicro2164. 
2. Warny M, Pepin J, Fang A, Killgore G, Thompson A, Brazier $\mathrm{J}$, et al. Toxin production by an emerging strain of Clostridium difficile associated with outbreaks of severe disease in North America and Europe. Lancet 2005; 366: 1079-1084, doi: 10.1016/S0140-6736(05)67420-X.

3. Nagy E. What do we know about the diagnostics, treatment and epidemiology of Clostridioides (Clostridium) difficile infection in Europe? J Infect Chemother 2018; 24: 164-170, doi: 10.1016/j.jiac.2017.12.003.

4. Elliott B, Androga GO, Knight DR, Riley TV. Clostridium difficile infection: Evolution, phylogeny and molecular epidemiology. Infect Genet Evol 2017; 49: 1-11, doi: 10.1016/ j.meegid.2016.12.018.

5. Just I, Fritz G, Aktories K, Giry M, Popoff MR, Boquet $P$, et al. Clostridium difficile toxin $B$ acts on the GTP-binding protein Rho. J Biol Chem 1994; 269: 10706-10712.

6. Just I, Selzer J, von Eichel-Streiber C, Aktories K. The low molecular mass GTP-binding protein Rho is affected by toxin A from Clostridium difficile. J Clin Invest 1995; 95: 10261031, doi: 10.1172/JCl117747.

7. Brito GA, Fujji J, Carneiro-Filho BA, Lima AA, Obrig T, Guerrant RL. Mechanism of Clostridium difficile toxin A-induced apoptosis in T84 cells. J Infect Dis 2002; 186: 1438-1447, doi: 10.1086/344729.

8. Brito GA, Carneiro-Filho B, Oria RB, Destura RV, Lima AA, Guerrant RL. Clostridium difficile toxin A induces intestinal epithelial cell apoptosis and damage: role of GIn and Ala-GIn in toxin A effects. Dig Dis Sci 2005; 50: 1271-1278, doi: 10.1007/s10620-005-2771-x.

9. Rodrigues RS, Oliveira RA, Li Y, Zaja-Milatovik S, Costa LB, Braga-Neto BM, et al. Intestinal epithelial restitution after TcdB challenge and recovery from Clostridium difficile infection in mice with alanyl-glutamine treatment. $J$ Infect Dis 2013; 207: 1505-1515, doi: 10.1093/infdis/jit041.

10. Bezerra Lima B, Faria Fonseca B, da Graca Amado N, Moreira Lima D, Albuquerque Ribeiro R, Garcia Abreu J, et al. Clostridium difficile toxin A attenuates Wnt/beta-catenin signaling in intestinal epithelial cells. Infect Immun 2014; 82: 2680-2687, doi: 10.1128/IAI.00567-13.

11. Alcantara C, Stenson WF, Steiner TS, Guerrant RL. Role of inducible cyclooxygenase and prostaglandins in Clostridium difficile toxin A-induced secretion and inflammation in an animal model. $J$ Infect Dis 2001; 184: 648-652, doi: 10.1086/ 322799.

12. Koon HW, Shih DQ, Hing TC, Yoo JH, Ho S, Chen X, et al. Human monoclonal antibodies against Clostridium difficile toxins $A$ and $B$ inhibit inflammatory and histologic responses to the toxins in human colon and peripheral blood monocytes. Antimicrob Agents Chemother 2013; 57: 3214-3223, doi: 10.1128/AAC.02633-12.

13. Beinortas $\mathrm{T}$, Burr NE, Wilcox MH, Subramanian V. Comparative efficacy of treatments for Clostridium difficile infection: a systematic review and network meta-analysis. Lancet Infect Dis 2018; 18: 1035-1044, doi: 10.1016/S1473-3099 (18)30285-8

14. Warren CA, van Opstal EJ, Riggins MS, Li Y, Moore JH, Kolling $\mathrm{GH}$, et al. Vancomycin treatment's association with delayed intestinal tissue injury, clostridial overgrowth, and recurrence of Clostridium difficile infection in mice. Antimicrob Agents Chemother 2013; 57: 689-696, doi: 10.1128/ AAC.00877-12.
15. Linden J. Adenosine in tissue protection and tissue regeneration. Mol Pharmacol 2005; 67: 1385-1387, doi: 10.1124/mol.105.011783.

16. Antonioli L, Csoka B, Fornai M, Colucci R, Kókai E, Blandizzi C, et al. Adenosine and inflammation: what's new on the horizon? Drug Discov Today 2014; 19: 10511068, doi: 10.1016/j.drudis.2014.02.010.

17. Zaynagetdinov R, Ryzhov S, Goldstein AE, Yin H, Novitskiy SV, Goleniewska K, et al. Attenuation of chronic pulmonary inflammation in A2B adenosine receptor knockout mice. Am J Respir Cell Mol Biol 2010; 42: 564-571, doi: 10.1165/ rcmb.2008-03910C.

18. Hasko G, Pacher P. A2A receptors in inflammation and injury: lessons learned from transgenic animals. J Leukoc Biol 2008; 83: 447-455, doi: 10.1189/jlb.0607359.

19. Warren CA, Li Y, Calabrese GM, Freire RS, Zaya-Milatovik $S$, Van Opstal E, et al. Contribution of adenosine A(2B) receptors in Clostridium difficile intoxication and infection. Infect Immun 2012; 80: 4463-4473, doi: 10.1128/IAI. 00782-12.

20. Cavalcante IC, Castro MV, Barreto AR, Sullivan GW, Vale M, Almeida PR, et al. Effect of novel A2A adenosine receptor agonist ATL 313 on Clostridium difficile toxin A-induced murine ileal enteritis. Infect Immun 2006; 74: 2606-2612, doi: 10.1128/IAI.74.5.2606-2612.2006.

21. Christofi FL, Zhang H, Yu JG, Guzman J, Xue J, Kim M, et al. Differential gene expression of adenosine A1, A2a, $\mathrm{A} 2 \mathrm{~b}$, and $\mathrm{A} 3$ receptors in the human enteric nervous system. J Comp Neurol 2001; 439: 46-64, doi: 10.1002/ cne.1334.

22. D'Auria KM, Kolling GL, Donato GM, Warren CA, Gray MC, Hewlett EL, et al. In vivo physiological and transcriptional profiling reveals host responses to Clostridium difficile toxin A and toxin B. Infect Immun2013; 81: 3814-3824, doi: 10.1128/IAI.00869-13.

23. Kuehne SA, Cartman ST, Minton NP. Both, toxin A and toxin $\mathrm{B}$, are important in Clostridium difficile infection. Gut Microbes 2011; 2: 252-255, doi: 10.4161/gmic.2.4.16109.

24. Riegler M, Sedivy R, Pothoulakis C, Hamilton G, Zacheri J, Bischof $G$, et al. Clostridium difficile toxin $B$ is more potent than toxin $\mathrm{A}$ in damaging human colonic epithelium in vitro. J Clin Invest 1995; 95: 2004-2011, doi: 10.1172/JCl117885.

25. Chen X, Katchar K, Goldsmith JD, Nanthakumar N, Cheknis A, Gerding DN, et al. A mouse model of Clostridium difficileassociated disease. Gastroenterology 2008; 135: 1984-1992, doi: 10.1053/j.gastro.2008.09.002.

26. Martins CS, Leitao RF, Costa DV, Melo IM, Santos GH, Lima V, et al. Topical HPMC/S-nitrosoglutathione solution decreases inflammation and bone resorption in experimental periodontal disease in rats. PLoS One 2016; 11: e0153716, doi: 10.1371/journal.pone.0153716.

27. Schmittgen TD, Livak KJ. Analyzing real-time PCR data by the comparative $\mathrm{C}(\mathrm{T})$ method. Nat Protoc 2008; 3: 11011108, doi: $10.1038 /$ nprot.2008.73.

28. Bayer EA, Wilchek $M$. The use of the avidin-biotin complex as a tool in molecular biology. Methods Biochem Anal 1980; 26: 1-45, doi: 10.1002/9780470110461.ch1.

29. Hsu SM, Raine L, Fanger $\mathrm{H}$. The use of antiavidin antibody and avidin-biotin-peroxidase complex in immunoperoxidase technics. Am J Clin Pathol 1981; 75: 816-821, doi: 10.1093/ ajcp/75.6.816. 
30. Haskó G, Pacher P. A2A receptors in inflammation and injury: lessons learned from transgenic animals. $J$ Leukoc Biol 2008; 83: 447-455, doi: 10.1189/jlb.0607359.

31. Cronstein BN. Adenosine, an endogenous anti-inflammatory agent. J Appl Physiol (1985) 1994; 76: 5-13.

32. Sullivan GW, Rieger JM, Scheld WM, Macdonald TL, Linden J. Cyclic AMP- dependent inhibition of human neutrophil oxidative activity by substituted 2-propynylcyclohexyl adenosine $\mathrm{A}(2 \mathrm{~A})$ receptor agonists. $\mathrm{Br} \mathrm{J}$ Pharmacol 2001; 132: 1017-1026, doi: 10.1038/sj.bjp.0703893.

33. Bouma MG, van den Wildenberg FA, Buurman WA. Adenosine inhibits cytokine release and expression of adhesion molecules by activated human endothelial cells. Am J Physiol 1996; 270: C522-C529, doi: 10.1152/ajpcell.1996.270.2.C522.

34. de Araujo Junqueira AF, Dias AA, Vale ML, Spilborghs GM, Bossa AS, Lima BB, et al. Adenosine deaminase inhibition prevents Clostridium difficile toxin A-induced enteritis in mice. Infect Immun 2011; 79: 653-662, doi: 10.1128/IAI.01159-10.

35. Wei W, Du C, Lv J, Zhao G, Li Z, Wu Zet al. Blocking A2B adenosine receptor alleviates pathogenesis of experimental autoimmune encephalomyelitis via inhibition of IL-6 production and Th17 differentiation. J Immunol 2013; 190: 138-146, doi: 10.4049/jimmunol.1103721.
36. Kolachala V, Asamoah V, Wang L, Obertone TS, Ziegler $T R$, Merlin D, et al. TNF-alpha upregulates adenosine $2 b(A 2 b)$ receptor expression and signaling in intestinal epithelial cells: a basis for A2bR overexpression in colitis. Cell Mol Life Sci 2005; 62: 2647-2657, doi: 10.1007/ s00018-005-5328-4.

37. Kuehne SA, Cartman ST, Heap JT, Kelly ML, Cockayne A, Minton NP. The role of toxin A and toxin B in Clostridium difficile infection. Nature 2010; 467: 711-713, doi: 10.1038/ nature09397.

38. Kolachala V, Ruble B, Vijay-Kumar M, Wang L, Mwangi S, Figler $\mathrm{H}$, et al. Blockade of adenosine $A 2 B$ receptors ameliorates murine colitis. $\mathrm{Br} J$ Pharmacol 2008; 155: 127-137, doi: 10.1038/bjp.2008.227.

39. Sitaraman SV, Merlin D, Wang L, Wong M, Gewirtz AT, Si-Tahar M, et al. Neutrophil-epithelial crosstalk at the intestinal lumenal surface mediated by reciprocal secretion of adenosine and IL-6. J Clin Invest 2001; 107: 861-869, doi: 10.1172/JCl11783.

40. Panther E, Idzko M, Herouy $\mathrm{Y}$, Rheinen H, Gebicke-Haerter PJ, Mrowietz U, et al. Expression and function of adenosine receptors in human dendritic cells. FASEB $J$ 2001; 15: 1963-1970, doi: 10.1096/fj.01-0169com. 